\title{
Reconstruction of Separate-Creditor Positions in the Process Declaring Bancruptcy in Indonesia Based on Justice Value
}

\author{
Supri Yono", Adi Sulistiyono ${ }^{2}$, Anis Mashdurohatun ${ }^{2}$, Ratih Mega Puspa Sari ${ }^{2}$ \\ ${ }^{1}$ Doctorate Student of Faculty of Law Sultan Agung Islamic University Semarang, Indonesia \\ ${ }^{2}$ Faculty of Law Sultan Agung Islamic University Semarang, Indonesia
}

DOI: $10.36348 /$ sijlcj.2020.v03i11.001

| Received: 13.10.2020 | Accepted: 29.10.2020 | Published: 03.11.2020

*Corresponding author: Supri Yono

\section{Abstract}

The problem discussed in this study involves is that there is yet to be a law protection for Multiple or Separate-Editor in case if company is declared bankrupt and is unable to pay its debts as a whole that could reflect Justice Value. The method of research used in this research is juridical-empirical where the research type is qualitative research with a sociological juridical approach (Socio-Legal Approach). The results of this study indicate that the position of the separate-creditors in the company bankruptcy currently has a priority in obtaining repayment of their accounts. Manpower legal protection in the event of a debtor who has been declared bankrupt before and after the Constitutional Court decision No. 67 / PUU-XI / 2013 are as follows: prior to the Constitutional Court decision it was assumed that labor wages remained under separate-creditors, taxes, auction fees, and curator fees and were deemed not to contradict Article 28D paragraph (1) and paragraph (2) of the Indonesian Constitution Law Year 1945. After the Constitutional Court decision, the position of workers' wages according to the Bankruptcy Law and the Civil Code takes precedence. The reconstruction of the position of the separate-creditor as offered by the author is by reconstructing the decision of the Constitutional Court No. 67 / PUU-XI / 2013 to better reflect the value of justice.

Keywords: Reconstruction, Separate-Creditor, Bankruptcy, Justice Value.

Copyright $\odot 2020$ The Author(s): This is an open-access article distributed under the terms of the Creative Commons Attribution 4.0 International License (CC BY-NC 4.0) which permits unrestricted use, distribution, and reproduction in any medium for non-commercial use provided the original author and source are credited.

\section{INTRODUCTION}

Universally, the Bankruptcy Law which was passed by the Indonesian People's Representative Council in Indonesia aims to regulate and prevent the settlement of bankruptcy cases that could lead to the end of detrimental to one of the parties, both Creditors and Debtors. Therefore, the settlement of cases in court can be done by combining three things, namely legal certainty, legal benefits, and legal justice [1]. In this regard, it also applies to the handling of bankruptcy cases at the Commercial Court which is guaranteed to be implemented by the Bankruptcy Law. In another case, the enforcement of bankruptcy law, the principle of fair debt repayment can be seen as the underlying form of injustice, that is; The principle of bankruptcy regarding unfair response is the Creditorium Parity principle even though it is a response to such injustice, if the Creditorium Parity principle is applied in a letter, it will lead to injustice, where the injustice of the Creditorium Parity principle is that creditors are the same as creditors and other creditors.
The principle of Creditorium Parity does not differentiate between the treatment of creditors, whether they are creditors with large receivables or creditors with small receivables, creditors holding collateral, and creditors who do not hold collateral at all. The principle of Equal Position of Creditors determines that creditors have equal rights to all debtors' assets [2]. If the debtor is unable to pay the debt, the debtor's assets will become the creditor's target. The principle of Creditorium Parity means that all debtor's assets, whether in the form of movable property or assets that are currently owned by the debtor and goods in the future will be owned by the debtor, are bound to the settlement of debtor's obligations. The principle of Creditorium Parity is regulated in the provisions of Article 1131 of the Civil Code which reads: "All objects of the debtor, both movable and immovable, both existing and new will be borne in the future for all individual engagements".

In certain cases, creditors also have the possibility to act arbitrarily on debtors through coercion in various ways so that the Debtors pay their debts. 
Therefore, the Bankruptcy Law functions to prevent Debtor actions that can harm Creditors and at the same time to prevent Creditors from acting arbitrarily to Debtors who are unable to pay their debts. The existence of the Bankruptcy Law is a form of legal protection provided by the state for these parties so that bankruptcy cases can be resolved properly and repayment of creditors' debts from the sale of bankruptcy assets can be carried out fairly.

The problems that occurred between creditors and debtors had happened to PT. Telkomsel and PT. Prima Jaya. Based on the Decision of the Commercial Court No. 48 /Pailit/ 2012 / Pn.Niaga.Jkt.Pst. stated that in mid-September 2012 PT.Telkomsel was declared bankrupt by the Central Jakarta Commercial Court. This is a surprise Given that PT. Telkomsel is one of the largest telecommunication operators in Indonesia subject to bankruptcy decisions and this declaration happened because the asset value of PT. Telkomsel, which reaches a value of up to trillions of rupiah is still low compared to how much debt owned by PT. Telkomsel at the time. In its decision, the Central Jakarta Commercial Court finally granted the bankruptcy petition submitted by PT. Prima Jaya Informatics where PT. Telkomsel filed this decision on cassation to the Supreme Court then [3]. The creditors' position in bankruptcy is basically the same and therefore they have the same rights on the outcome of the execution of the bankruptcy bill according to the size of their respective bills.

However, this principle recognizes exceptions, namely the creditors who hold collateral rights over the material and the creditors whose rights take precedence under the bankruptcy law and other laws and regulations. Thus the principle of Creditorium Parity applies only to concurrent creditors.

The important problem is what if a company is declared bankrupt and is unable to pay its debt as a whole. This means that if the assets of the bankrupt company are not sufficient to pay all of its debts, the road to debt restructuring through peace will not be created. In such circumstances, the legal sector has the main function of aligning the interests of the rights and positions of each creditor, so as to achieve an element of justice by giving each creditor a share in accordance with their rights.

Bankruptcy or the dissolution of a company will have the potential to adversely affect the rights of creditors and workers. The interests of creditors and employees of a company that is declared bankrupt are related to the payment of debts against creditors and wages of workers.

Article 55 paragraph (1) of the Indonesian Bankruptcy Law states that "With due observance of the provisions as referred to in Article 56, Article 57, and Article 58, each creditor holding a pledge, fiduciary security, mortgage, mortgage, or other collateral rights, can exercise its rights as if there was no bankruptcy". The provisions of Article 55 paragraph (1) of the Bankruptcy Law emphasize that separate-creditors have a superior position in the bankruptcy process compared to other creditors so that according to the Bankruptcy Law, the position of the collateral rights holder takes precedence or is higher than other creditors. This group of creditors is not affected by the decision of the debtor's bankruptcy statement, meaning that their execution rights can still be exercised as if there was no debtor's bankruptcy.

Article 95 paragraph (4) of the Manpower Law also emphasizes that in the case of bankruptcy, the wages and other rights of the worker/laborer constitute a debt whose payment is prioritized. This conflict of interest is very influential in the bankruptcy settlement effort, especially if in the event of bankruptcy the separate-creditors meet the workers' wages. This problem is often the subject of debate if bankruptcy occurs.

Regarding this case, The Constitutional Court through its decision number 67 / PUU-XI / 2013 stated that:

1. Article 95 paragraph (4) of the Manpower Act (State Gazette of the Republic of Indonesia Number 4179) contradicts the 1945 Constitution of the Republic of Indonesia as long as it is not interpreted as: "payment of workers/laborers wages owed takes precedence over all types of creditors including the claims of separatecreditors, claims for state rights, auction offices, and public bodies established by the government, while payments for workers/laborers' rights take precedence over all claims including claims for state rights, auction offices, and public bodies formed by the Government, except for claims from separate-creditors";

2. Article 95 paragraph (4) of the Manpower Act (State Gazette of the Republic of Indonesia Number 4179) does not have binding legal force as long as it is not interpreted: the state, auction offices, and public bodies established by the government, while payment of other workers/laborers rights takes precedence over all claims including claims for state rights, auction offices and public bodies established by the Government, except for claims from separatecreditors.

Based on the decision of the Constitutional Court, it can be concluded that workers' wages are prioritized in the event of bankruptcy against claims by separate-creditors, claims for state rights, auction offices, and public bodies formed by the government. This can lead to legal uncertainty in the provisions of the Bankruptcy Law and the existing Collateral Law, and maybe one day financiers (especially banks) as 
separate-creditors will be reluctant to provide loans to their customers to get business capital to earn income and a standard of living which is good because there is less guarantee for a refund due to having a very weak position [4].

Based on the various problems above, the authors are interested in discussing them in a study with the following issues:

1. How is the Current law protection of SeparateCreditors in the event of a debtor who has been declared bankrupt in Indonesia before and after the Constitutional Court decision no. 67 / PUU-XI / 2013 ?

2. How is the reconstruction of the position of the separate-creditors related to the Constitutional Court decision No. 67 / PUU-XI / 2013 in the declaration of bankruptcy process based on a just legal certainty?

\section{METHOD OF RESEARCH}

The paradigm that is used in the research this is the paradigm of constructivism which is the antithesis of the understanding that lay observation and objectivity in finding a reality or science knowledge [5]. Paradigm also looked at the science of social as an analysis of systematic against Socially Meaningful Action through observation directly and in detail to the problem analyzed.

The research type used in writing this paper is a qualitative research. Writing aims to provide a description of a society or a certain group of people or a description of a symptom or between two or more symptoms.

Approach method used in this research is Empirical-Juridical [6], which is based on the norms of law and the theory of the existing legal enforceability of a law viewpoint as interpretation.

As for the source of research [7] used in this study are :

1. Primary Data, is data obtained from information and information from respondents directly obtained through interviews and literature studies.

2. Secondary Data, is an indirect source that is able to provide additional and reinforcement of research data. Sources of secondary data in the form of: Primary Legal Material and Secondary Legal Materials and Tertiary Legal Material.

In this study, the author use data collection techniques, namely literature study, interviews and documentation where the researcher is a key instrument that is the researcher himself who plans, collects, and interprets the data. Qualitative data analysis is the process of searching for, and systematically compiling data obtained from interviews, field notes and documentation by organizing data into categories, describing it into units, synthesizing, compiling into patterns, selecting important names and what will be studied and make conclusions.

\section{RESEARCH RESULT AND DISCUSSION}

The Current Law Protection Of SeparateCreditors In The Event Of A Debtor Who Has Been Declared Bankrupt In Indonesia Before And After The Constitutional Court Decision No. 67 / PUU-XI / 2013

The position of workers as creditors in the Burgerlijk Wetboek (Indonesian Civil Code) is regulated, in Article 1138 Burgerlijk Wetboek, Article 1139 Burgerlijk Wetboek, and Article 1149 Burgerlijk Wetboek. Burgerlijk Wetboek has a Structured Creditor Principal, which is based on Articles 1131-1138 Burgerlijk Wetboek. The purpose of implementing this principle is to prevent debtors from avoiding their obligations to pay debts to creditors and not fighting over assets which will later become bankrupt assets.

As in Burgerlijk Wetboek, creditors are divided into three types, namely concurrent creditors, preferred creditors, and separate-creditors. Concurrent creditors as one type of creditor are regulated in Article 1132 Burgerlijk Wetboek. These concurrent creditors are creditors with the right to Pare Passu Pro Rata Parte which means that the concurrent creditors have the same position or repayment of debts from the assets of the debtor without any priorities. Preferred creditors, are creditors who by law, solely due to the nature of the debt, get paid in full first. Preferred creditors are creditors who have special privileges, namely a right which is given by law to a debtor so that the level is higher than other debtors, solely based on the nature of the debt.

The last creditors are separate-creditors, namely creditors who hold property security rights in rem, which in Burgelijk Wetboek are called pawns and mortgages. Currently, the Indonesian guarantee law system recognizes 4 (four) types of collateral, including mortgage, pawn, mortgage and fiduciary.

Regulations regarding the position of workers are also regulated in the bankruptcy law. The principle of structured Pro Rata or also known as structured creditors [8]. this principle is one of the principles in bankruptcy law that provides a solution or justice among creditors. This principle is the principle that classifies and classifies various kinds of debtors according to their respective classes.

The normative application of the structured Creditors principle in the Indonesian bankruptcy law may refer to Article 1 paragraph (1) of Law Number 4 of 1998 concerning Bankruptcy. This article discloses the coverage of all creditors under the bankruptcy law, namely separate-creditors, preferred creditors, and concurrent creditors. Likewise, Law Number 37 of 2004 concerning Bankruptcy and Postponement of Debt 
Payment Obligations regulates the same thing. Article 2 paragraph (1) states that a debtor who has two or more creditors and does not pay in full at least one overdue debt can be declared bankrupt by a court decision. This article also includes the meaning of all creditors, namely separate-creditors, preferred creditors and concurrent creditors.

The placement of workers' positions under separate-creditors can be seen from Article 55 paragraph (1) of Law Number 37 of the Year 2004 concerning Bankruptcy and Postponement of Debt Payment Obligations. This article states that the separate-creditors (creditors holding the right to guarantee the material) can exercise their rights directly as if there was no bankruptcy. The existence of this right shows that the guarantees held by the separatecreditors are not part of the bankruptcy estate so that they can be executed directly themselves.

In the Indonesian bankruptcy law, the separatecreditor as the creditor holding the security right is the creditor with the right to guarantee material that is born from the guarantee agreement which is an integral part of the agreement that arises from a debt agreement with a guarantee of security rights born from this kind of agreement and has two characters, namely prioritized for the fulfillment of the agreement attached to the guarantee of said object (Droit Preference) and with this dependence, the Guarantee right will always be attached to the party who guarantees (Droit de Suite).

The problems discussed in this study are about labor legal protection in the event that the debtor has been declared bankrupt before the Constitutional Court decision No. 67 / PUU-XI / 2013, to find out more about the protection of workers, including cases the Decision of the Commercial Court in PT. Daya Guna Samudra versus William Eduard Daniel, curator of PT. Daya Guna Samudra, Number 32 /Pailit/2004/ PN.Niaga/Jkt.Pst. In the decision of the Central Jakarta Commercial Court, there is also a decision that resolves debts originating from wages or severance pay when workers are dismissed when the company is declared bankrupt [9].

Debtor workers of PT. Daya Guna Samudra filed an appeal against the Commercial Court decision filed by William Eduard Daniel as the curator of PT. Daya Guna Samudra. This petition originated from the declared bankruptcy of PT. Daya Guna Samudra for the development of PT. Daya Guna Samudra. Then William Eduard Daniel was appointed as a curator of PT. Daya Guna Samudra in bankruptcy. The curator stated to the workers or laborers of PT. Daya Guna Samudra in bankruptcy, that the company will not continue its operations or business activities and will not continue working relations with workers and laborers of PT. Daya Guna Samudra in bankruptcy. This decision was made based on the fact that PT. Daya
Guna Samudra in bankruptcy has stopped all business activities as of June 28, 2004, and the company has no ability to pay workers or labor salaries since July 2004.

Furthermore, regarding the termination plan, the PT. Daya Guna Samudra submits a claim that workers or laborers receive severance pay of $\mathrm{Rp}$. $28,926,938,439.00$ which is calculated from twice the provisions of Article 156 paragraph (2) of Law Number 13 of the Year 2003 concerning Manpower, including reward money and compensation for rights. All of this is calculated until the salary payable in July 2004 and August 2004 to August 192004 and the holiday allowance of one month's salary.

Regarding the request of the curator, the Central Jakarta Commercial Court adopted a decision which, among other things, stated that in the subject of the request to accept the request of the curator, it stated that it granted the worker or laborer's claim once the provisions of Article 156 paragraph (2) of Law Number 13 of 2003 concerning Manpower, along with the award money, namely one time the provisions of Article 156 paragraph (3) and replacement of rights, namely one time the provisions of Article 156 paragraph (4). Everything is calculated until the end of June 2004 for the number of workers or laborers of 1,875 people plus the salary payable in July 2004, and holiday allowances of one month's salary.

With regard to the decision of the Commercial Court of PT. Daya Guna Samudra filed an appeal with several objections. First, the Judex Factie (Evidence Examination Process) has erred in its judgment stating that the Judex Factie has the authority to examine, try, and decide on the request for dispute settlement claims for PT. Daya Guna Samudra Tbk is in bankruptcy. The effort questioned by the curator is basically a dispute about the magnitude of the normative rights of PT. Daya Guna Samudra, namely in the form of severance pay, a period of service pay, compensation for rights, and wages payable arising from the curator's intention to terminate the employment relationship due to the bankruptcy of PT. Daya Guna Samudra. Thus, the dispute is actually a dispute regarding industrial relations, the settlement of which is the absolute authority of the Industrial Relations Dispute Settlement Institution as regulated in Article 151 paragraph (3) of Law Number 13 of 2003 concerning manpower as until now, the only institutions that have been contradicting the determination of mass layoffs are the Central Labor Dispute Resolution Committee or the Central Labor Dispute Resolution Committee.

Next, the Judex Factie has been wrong and wrong in applying the law in its decision to grant the curator's request to pay the workers' rights in the form of wages owed only limited to the wages payable until PT. Daya Guna Samudra August 19, 2004, because the bankruptcy declaration did not result in a legal 
termination of the Work relationship between the company and the workers which resulted in the elimination of the company's obligation to continue paying wages to workers.

The Supreme Court in its decision gave consideration by arguing regardless of the objections raised by the debtor worker of PT. Daya Guna Samudra. The Supreme Court is of the opinion that the main dispute in a quo petition is a dispute over differences in the number of the bankruptcy debtor's liabilities demanded by his employees. This problem is a renvoi process, which is included in the scope or stages of the management and settlement of bankruptcy assets, which means that there is no legal remedy for cassation. Thus the request for cassation was rejected.

The Decision of the Commercial Court in relation to the protection of workers or labor rights if the company where they work is declared bankrupt before the Constitutional Court Decision No. 67 / PUUXI / 2013, had at least three views. First, the decision rejecting the workers 'or laborers' wages and severance pay as bankruptcy debt. This is because when workers or laborers submit a bankruptcy request to the Commercial Court, the rights of workers in the form of wages and severance pay are still in dispute at the State Administrative Court and do not yet have binding legal force. Second, the decision of the Commercial Court which places the wage position of a worker or laborer not as a special creditor because according to the law, the workers' rights have their position as preferred creditors. Although in other decisions the Supreme Court recognizes the position of workers or laborers as special creditors. And the Third, the decision of the Commercial Court which provides protection for the interests of workers or laborers.

In 2014, through Decision Number 67 / PUUXI / 2013, the Constitutional Court granted part of the lawsuit/demand for the judicial review of Article 95 paragraph (4) of the Manpower Law. The essence of the decision is that if the company goes bankrupt, the payment of the workers' wages owed will take precedence over all types of creditors, including claims by separate-creditors, claims for state rights, auction offices, and public bodies established by the government. Furthermore, it was also decided that other workers' rights should be paid in advance of all kinds of bills including claims for state rights, auction offices, and public bodies formed by the government, except for claims from separate-creditors.

The Constitutional Court's decision has a wide influence because it not only affects the implementation of the Manpower Law but also a number of laws and regulations, including Law Number 37 of 2004 concerning Bankruptcy and Postponement of Debt Payment (Bankruptcy Law); The Civil Code, Law Number 28 of the Year 2007 concerning General
Provisions and Tax Procedures (KUP), and Law Number 4 of the Year 1996 regarding Mortgage Rights to Land and Objects Related to Land (Mortgage Law).

The impact can be seen from the variety of judges' decisions related to the Constitutional Court's decision, including the decision of the judge for bankruptcy. There are court decisions that support such as in the bankruptcy case of PT Integra Lestari (Decision Number 24/Plw.Pailit/PN.Niaga.Sby jo. Number 06/Pailit/2013/PN.Niaga.Sby). The Decision of the Surabaya District Court emphasizes that the position of paying workers' wages is higher than paying tax bills. However, there are also court decisions that ignore the Constitutional Court Decision Number 67 / PUU-XI / 2013, such as Bandung Industrial Relations Court (PHI) Decision Number 75 / Pdt.Sus-PHI / 2016 / PN.Bdg.

This decision places collateral seizure (civil confiscation) of the bankruptcy estate. This condition had made workers worried about the fate of their wage payments. Although later the Supreme Court affirmed the Bandung PHI decision so as not to contradict the Constitutional Court Decision Number 67 / PUU-XI / 2013 through the Supreme Court Decision Number 1120 K / Pdt.Sus-PHI / 2017, which reads "That the reason for the Cassation Petitioner was that Judex Factie exceeded the confiscated guarantee petitioned, it cannot be justified because regarding the laying of confiscation it is linked to guarantees so that workers' rights can be fulfilled which is the authority of the court ".

The Decision of the Panel of Justices of the Constitutional Court in deciding case No. The first 67 / PUU-XI / 2013, namely that workers/laborers are socially and economically weaker than entrepreneurs/investors, so legally it is appropriate for workers/laborers to receive equal and fair treatment as Article 28D paragraph (1) of the 1945 Constitution states that "Everyone has the right to recognition, guarantee, protection, and legal certainty that is just and equal treatment before the law". This is a reference for workers/laborers because workers/laborers are also Indonesian citizens protected by the 1945 Constitution who is entitled to recognition, guarantees, protection, and legal certainty that is just and equal treatment before the law.

Second, that workers/laborers' wages must take precedence based on Article 28D paragraph (2) of the 1945 Constitution which clearly states that "Everyone has the right to work and to receive fair and proper compensation and treatment in a work-related relationship". This article clearly states that workers/laborers who are part of the development of the State have the right to work and receive compensation in order to fulfill the basic needs of life for themselves and their families because human interests in themselves and their lives must be a priority. The 
worker/laborer wage is actually a debt of the entrepreneur/investor to the worker/laborer who should be paid for what he earned. So it is natural that workers/laborers 'wages take precedence because workers/laborers' wages are a constitutional right as referred to in Article 28D paragraph (2) of the 1945 Constitution.

Third, when compared with the obligations to the State, namely taxes, the wages of workers/laborers should take precedence because according to Fritz Neumark the tax function is Fiscal or Budgetary Function, Economic Function, and Social Function, which all of these tax functions mean that the tax function is to stabilize the economy, preventing unemployment, and economic growth. If you do not prioritize the payment of workers/laborers 'wages when the company goes bankrupt, it is feared that unstable economic turmoil may occur due to workers/laborers' source of life not being implemented, which will cause slow economic growth. Apart from that, the State also has other sources of financing besides taxes, while workers/laborers, namely wages, are the only source to sustain life for themselves and their families.

\section{Reconstruction of the Position of the Separate- Creditors Related To the Constitutional Court Decision No. 67 / PUU-XI / 2013 in the Declaration of Bankruptcy Process Based On A Just Legal Certainty}

Based on the Decision of the Constitutional Court Number 67/PUU-XI/2013, in the event of bankruptcy, workers' wages now have a higher position than that of separate-creditors. However, this only applies to workers' wages. Regarding workers' claims in the form of other rights such as severance pay, separatecreditors still have a higher position than workers' wages. This is as stated in the ruling which has made two new norms stating that the payment of indebted labor workers' wages takes precedence over all types of creditors including on separate-creditor bills, state bills, auction offices, and public bodies formed by the government. Meanwhile, the payment of other workers' rights takes precedence over all types of bills, including claims for the rights of the State, auction offices, and public bodies formed by the government, except for claims by separate-creditors [10].

Furthermore, Article 10 paragraph (1) letter a, of Law Number 24 of 2003 concerning the Constitutional Court states that "The Constitutional Court has the authority to judge at the first and last levels whose decisions are final to test the Law against the 1945 Constitution of the Republic of Indonesia."

From the explanation above, the Constitutional Court decision can immediately gain permanent legal force since it is pronounced and no legal remedy can be taken. The final nature of the Constitutional Court's decision in this Law also includes the final and binding legal force [11]. Thus, it can be seen that the regulations regarding the position of separate-creditors and workers' wages must run in accordance with the provisions of the Constitutional Court decision.

Based on the decision of the Constitutional Court, it can be concluded that the provisions stipulated in Article 55 paragraph (1) of the Bankruptcy Law which gives priority and separate position to separatecreditors in obtaining repayment of their debts after the issuance of the decision of the Constitutional Court Number 67/PUU-XI /2013 now this does not apply to preferred creditors 'claims in the form of workers' wages. The provisions of the Constitutional Court Decision have also been applied to existing bankruptcy practices. Where after the decision of the issuance of the Constitutional Court Number 67 / PUUXI / 2013, in practice, in the event of bankruptcy, workers' wages now have a higher position than that of separatecreditors by getting their receivables paid in advance rather than bills from separate-creditors.

The priority order of debt repayments in the bankruptcy process after the Constitutional Court decision Number 67/PUU-XI/2013 is determined in the event that the collateral is executed by separatecreditors; If the collateral is executed by the separatecreditor himself pursuant to Article 55 paragraph (1) jo. Article 59 paragraph (1) of the Bankruptcy Law and PKPU, the auction fees and sales tax for the collateral object will be borne by the separate-creditors. If there are still sales proceeds as referred to in Article 60 paragraph (1) of the Bankruptcy Law and PKPU, or because the assets of the bankrupt debtor are not entirely guaranteed to the separate-creditors so that there are other bankrupt assets, then the remaining proceeds from the sale or other bankruptcy assets these will be paid to creditors in the following order:

a) Curator Fee and Declaration of Bankruptcy Fee with the legal basis for this in Article 191 of the Bankruptcy Act;

b) Labor Wages with the Legal basis in Decision Number 67 / PUU-XI / 2013

c) Tax debt with the Legal Basis in Article 21 of the Law on Tax Procedures;

d) Creditors with special privileges. Included in this class of creditors is mentioned in Article 1139 of the Civil Code numbers 1 to 9, provided that Article 1139 point 1 of the Civil Code is above the separate-creditors, namely as bankruptcy fees. The legal basis of Article 1138 of the Civil Code jo. Article 1139 of the Civil Code;

e) Creditors with general privileges. Included in this class of creditors is mentioned in Article 1149 of the Civil Code number 1 to 7, provided that Article 1149 point 1 of the Civil Code is domiciled above separate-creditors, namely as a bankruptcy fee. Legal basis of Article 1138 jo. 1149 Civil Code; 
f) Concurrent creditors where the legal basis is contained in Article 1132 of the Indonesian Civil Code.

In the event that the collateral is executed by the curator, then if a separate-creditor fails to execute his collateral for the period permitted under Article 59 paragraph (1) of the Bankruptcy Law and PKPU, then based on Article 59 paragraph (2) the curator must demand that the collateral be handed over to be sold without reducing the rights of the separate-creditor. on the proceeds from the sale of the collateral.

Based on the explanation above, the reconstruction of the position of the separate-creditor in relation to the Constitutional Court decision No. 67/PUU-XI/2013 regarding the position of workers in the bankruptcy process based on fair legal certainty are as follows:

\section{Before Reconstruction:}

Article 59 of Law no. 37 of 2004 reads: Paragraph (1) With due observance of the provisions of Article 56, Article 57, and Article 58, Creditors holding the rights as referred to in Article 55 paragraph (1) must exercise their rights within a period of no later than 2 (two) months after commencement of the state of insolvency as referred to in Article 178 paragraph (1). Paragraph (2) After the expiration of the period as referred to in paragraph (1), the Curator must demand the delivery of the collateral for further sale according to the method referred to in Article 185, without prejudice to the rights of the Creditors of the right holder on the proceeds from the sale of the collateral. Paragraph (3) At any time the Curator may release the collateral object by paying the smallest amount between the market price of the collateral object and the amount of debt secured by the collateral object to the Creditors concerned.

\section{Weaknesses:}

If a separate-creditor fails to execute his collateral for the period permitted under Article 59 paragraph (1) of the Bankruptcy Law and PKPU, then based on Article 59 paragraph (2) the curator must demand the surrender of the collateral for further sale without reducing rights. separate-creditors for the proceeds from the sale of the collateral. However, this article does not yet provide normative rules regarding the order of payment of the proceeds from the sale of the collateral to creditors.

\section{After Reconstruction:}

Article 59 of Law no. 37 of 2004 reads: Paragraph (1) With due observance of the provisions of Article 56, Article 57, and Article 58, Creditors holding the rights as referred to in Article 55 paragraph (1) must exercise their rights within a period of no later than 2 (two) months after commencement of a state of insolvency as referred to in Article 178 paragraph (1).
Paragraph (2) After the time period as referred to in paragraph (1) has passed, the Curator must demand the delivery of the collateral for further sale in accordance with the method referred to in Article 185, without prejudice to the rights of the Creditors of the right holder on the proceeds from the sale of the collateral. Paragraph (3) proceeds from the sale of the collateral based on the provisions of paragraph (2) are paid to creditors as follows:

a) Curator Fee and Declaration of Bankruptcy Fee.

b) Labor Wages.

c) Tax debt.

d) Separate-Creditors.

e) Creditors with special privileges.

f) Creditors with general privileges.

g) Concurrent creditors.

With the Change of Paragraph (3) to Paragraph (4) then, the Curator can at any time release the collateral object by paying the smallest amount between the market price of the collateral object and the amount of debt secured by the collateral object to the Creditors concerned. thus making the law protection for the separate-creditor better in relfectiong the justice value.

\section{CONCLUSION}

1. Manpower's legal protection in the event of a debtor who has been declared bankrupt before the Constitutional Court Decision No. 67 / PUU-XI / 2013, does not take precedence. This caused by the difference of opinion and court decision before the Constitutional Court decision No. 67 / PUU-XI / 2013 has created legal uncertainty so that related to the position of workers' wages in bankruptcy, two judicial reviews have been conducted. After the Constitutional Court decision No. 67 / PUU-XI / 2013, the position of wages of workers according to the Bankruptcy Law and the Civil Code takes precedence. Wages of workers get their debts paid off before separate-creditors. This is a legal breakthrough of the provisions that have been regulated by the Bankruptcy Law and the applicable guarantee law. So it is clear that in case of bankruptcy, workers' wages have a higher position than that of separate-creditors.

2. Reconstruction of the position of the separatecreditors related to the Constitutional Court decision No. 67 / PUU-XI / 2013 in the bankruptcy process based on fair legal certainty based on the Constitutional Court Decision Number 67 / PUUXI / 2013, the petition is partially granted and there has been an overhaul by prioritizing worker wages compared to other creditors' claims. Basically the Constitutional Court Decision No. 67 / PUU-XI / 2013 has provided protection and legal certainty to workers to obtain their rights in the form of payment of wages and other rights in the bankruptcy process, however this conflicts with the Civil Code, Law Number 28 of the Year 2007, Law Number 4 of 1996 and Law No. 37 of 2004 
concerning Bankruptcy and Postponement of Debt Payment Obligations. Thus, the reconstruction of the separate-position related to the Constitutional Court decision No. 67 / PUU-XI / 2013 regarding the position of workers in the bankruptcy process based on fair legal certainty, namely as follows: If the collateral is executed by separate-creditors under Article 55 paragraph (1) jo. Article 59 paragraph (1) of the Bankruptcy Law and PKPU, the auction fees and sales tax for the collateral object will be borne by the separate-creditors. If there are still sales proceeds as referred to in Article 60 paragraph (1) of the Bankruptcy Law and PKPU, or because the assets of the bankrupt debtor are not entirely guaranteed to the separatecreditors so that there are other bankrupt assets, then the remaining proceeds from the sale or other bankruptcy assets these will be paid to creditors. If a separate-creditor fails to execute his collateral within the period permitted under Article 59 paragraph (1) of the Bankruptcy Law and PKPU, then based on Article 59 paragraph (2) the curator must demand the submission of the collateral for sale without prejudice to the rights of the separatecreditor. on the proceeds from the sale of the collateral.

\section{REFERENCES}

1. Sarwedi. (2002). Investasi Asing Langsung di Indonesia dan Faktor yang Mempengaruhinya, Jurnal Akuntansi dan Keuangan, 4(1):19.
2. Rahayu, H. (2008). Hukum Kepailitan, Malang, UMM Press, 22.

3. M Hadi, S. (2008). Hukum Kepailitan, Jakarta, Kencana, 28-29.

4. Makmur, S. (2018). Penerapan Undang-Undang Kepailitan dalam Menciptakan Iklim Berusaha Yang Sehat Bagi Seluruh Pelaku Usaha. Jurnal AJUDIKASI Vol, 2(1), 89-115.

5. Faisal. (2010). Menerobos Positivisme Hukum, Rangkang Education, Yogyakarta.

6. Johnny, I. (2005). Teori dan Metodologi Penelitian Hukum Normatif, Bayumedia, Surabaya.

7. Moleong, L. (2002). Metode Penelitian Kualitatif, PT Remaja Rosdakarya, Bandung.

8. Rachmat, R., \& Suherman, S. (2020). Perlindungan Hukum Terhadap Kreditor Pemegang Jaminan Fidusia Terhadap Harta Debitor Yang Dinyatakan Pailit. National Journal of Law, 3(2).

9. Fitasari, F. D. (2020). Keabsahan Permohonan Pailit Yang Diajukan Oleh Buruh Tanpa Putusan Pengadilan Hubungan Industrial. JuristDiction, 3(3), 971-990.

10. Hunter Jr, R. J., Shannon, J. H., Amoroso, H. J., \& Lozada, H. R. (2020). To Declare or Not to Declare [Bankruptcy]: That May Be the Question, A Tale of Bankruptcy in Higher Education. Education Quarterly Reviews, 3(2).

11. Widodo, W., Budoyo, S., \& Pratama, T. G. W. (2018). The role of law politics on creating good governance and clean governance for a freecorruption Indonesia in 2030. The Social Sciences, 13(8), 1307-1311. 